SECTION 20. Medicine.

Yakobchuk Elena Aleksandrovna nurse practitioner,

City hospital №1 of the town of Taraz, Kazakhstan

\title{
ANALYSIS AND DEVELOPMENT OF RECOMMENDATIONS FOR BREASTFEEDING
}

The recent increase in the number of women and girls to actively employed in the business, leading to some stable negative trends - directly affecting their health and the health of their infants.

Keywords: milk, disorders, recommendations.

\section{АНАЛИЗ И РАЗРАБОТКА РЕКОМЕНДАЦИЙ ДЛЯ ГРУДНОГО ВСКАРМЛИВАНИЯ}

Увеличение в последнее время числа женщин и девушек активно занятых в бизнесе, приводит к некоторым устойчивым негативным тенденциям - непосредственно влияющих на их самочувствие и здоровье их новорожденных детей.

Ключевые слова: молоко, паталогии, рекомендации.

\section{1. Введение}

Отказ от кормления грудью, постоянная занятость, психологические стрессы, приводят к паталогиям не только матери, но и нарушениям правильного роста и развития ребенка.

А ведь грудное молоко представляет собой самую лучшую и полезную для грудных детей пищу. Естественным является вскармливание ребенка грудным молоком. Оно содержит все необходимые питательные вещества, витамины, микроэлементы и полностью обеспечивает потребности детского организма в пищевых компонентах в первые месяцы жизни. А первые часы жизни новорожденного являются тем критическим периодом, когда происходит максимальное по интенсивности инфицирование окружающими микроорганизмами и вирусами [1]. Поэтому уделяется особое внимание к раннему прикладыванию к груди, в первые 20 - 30 минут, но не позже 2 часов после его рождения первичным молоком - молозивом. Молозиво очень хорошо соответствует специфическим потребностям детей; является важной промежуточной формой питания в период перехода ребенка от плацентарного перехода к энпиральному (лакторофному). Оно содержит высокое количество белка, более богато аминокислотами, чем переходное, зрелое молоко, и минеральных веществ, относительно бедно углеводами и жирами. 
Молозиво обеспечивает в небольшом объеме необходимое количество питательных веществ, которые усваиваются лучшим образом. Неразвившиеся почки новорожденного ребенка не могут перерабатывать большие объемы жидкостей, не испытывая метаболического стресса, поэтому небольшие объемы жидкостей и высокая плотность молозива очень хорошо соответствуют этой физиологической особенности. Первое кормление молозивом является мощным стимулирующим развитием и становление неспецифических естественных факторов защиты в силу того, что высокая концентрация ферментов, гормонов и других биологических веществ способствует активации незрелых пищеварительных и обменных функций новорожденных. Этот уникальный продукт, выделяющийся в первые 2 - 3 дня лактации, содержит все необходимые пищевые ингредиенты и факторы иммунологической защиты. В соответствии с принятыми рекомендациями, к груди матери прикладывают здоровых доношенных детей с оценкой по шкале Апгар не ниже 7 баллов. У детей, приложенных к груди матери в течение первого часа после рождения, отмечаются значительное снижение частоты инфекционновоспалительных заболеваний в первый год жизни, а так же снижение аллергических проявлений.

Грудное вскармливание полезно для здоровья матери, т.к. оно способствует сокращению матки после родов, помогает восстановить фигуру и является лучшей профилактикой мастопатии и рака молочной железы. К числу важнейших достоинств женского молока относятся: оптимальный и сбалансированный уровень пищевых веществ; высокая усвояемость женского молока организмом ребенка; наличие в молоке широкого спектра биологически активных веществ и защитных факторов (ферментов, гормонов, иммуноглобулинов и др.); благоприятное влияние на микрофлору кишечника; стерильность; оптимальная температура и др.

Биологическое значение женского молока. Здоровье, рост и гармоничное развитие ребенка зависят от характера питания. Особенно отчетливо это проявляется в первые дни жизни, когда происходит адаптация новорожденного к внеутробному существованию. Давно известно, что уровень заболеваемости и смертности детей, находящихся на грудном вскармливании, значительно ниже, чем детей, вскармливаемых искусственно. Известно, что после рождения происходит заселение кожи, слизистых оболочек органов дыхания и пищеварения вирусами и бактериальной флорой. Однако в первые дни жизни новорожденные отличаются низкой резистентностью, что наряду с анатомофизиологическими особенностями строения и функции отдельных систем обусловливается отсутствием активного иммунитета. Пассивный же иммунитет, который ребенок получает от матери, в основном обеспечивается антителами, относящимися к иммуноглобулину G. Заселение желудочно-кишечного тракта бактериальной флорой является 
одним из основных стимулов формирования активного иммунитета. Молозиво и переходное молоко, которые ребенок получает после рождения, иммунологически активны ко многим антигенам, так как в нем содержатся различные антитела. В грудном молоке обнаружены антитела к сапрофитическим и энтеропатогенным эшерихиям, шигеллам, энтеровирусам, кокковой флоре и др., а также неспецифические факторы защиты (макрофаги, лизоцим и др.). Секреторный иммуноглобулин А женского молока является первой линией защиты, предупреждающей развитие инфекции у ребенка. Кроме того, полагают, что лимфоциты женского молока (в 1 мл молозива находится 0,5-10 млн. клеток), попадая в желу-дочно-кишечный тракт ребенка, стимулируют местный иммунитет кишечника.

Состав грудного молока не постоянен, он изменяется во время кормлений, в зависимости от времени суток, а также в процессе лактации. Содержащиеся в материнском молоке макрофаги, иммунные антитела, повышают сопротивляемость детей к различным заболеваниям, в том числе желудочно-кишечным. Биологическое строение белков грудного молока схоже с белками сыворотки крови, и поэтому часть этих белков всасывается слизистой оболочкой желудка и переходит в кровь в неизменном состоянии. Грудное молоко формирует нормальную микрофлору кишечника т.к включает в себя бифидогенные факторы. В 1 литре грудного молока содержится от 11 до 15 г белков, 35 - 38 г жиров, $70-75$ г углеводов. Энергетическая ценность составляет $690-700$ ккал. Состав грудного молока и его количество зависят от состояния здоровья женщины, ее конституциональных особенностей, характера питания и от соблюдения режима. Грудное молоко характеризуется сбалансированностью белкового и жирового компонентов. Оно, в отличие от коровьего молока и смесей домашнего приготовления, содержит меньше белка. Белки женского молока богаты незаменимыми аминокислотами и хорошо усваиваются детским организмом. Только грудное молоко содержит некоторые незаменимые жирные кислоты, такие, как эссенциальные полиненасыщенные, выполняющие пластические функции и необходимые для нормального развития ребенка. При грудном вскармливании большое значение имеют количество и состав жира, так как $47 \%$ энергетической ценности женского молока покрывается за его счет. Жиры оказывают большое влияние на рост и развитие ребенка. Углеводы в женском молоке представлены до 90\% лактозой и являются основным источником быстроутилизируемой энергии. Усвоение лактозы происходит в тонкой кишке. Лактоза способствует всасыванию кальция, железа, цинка, магния и меди. Кроме лактозы в женском молоке содержится галактоза, необходимая для метаболических процессов в нервной клетке. Чрезвычайно важно то, что женское молоко содержит иммунологические и биологические активные вещества, антитела, которые защищают ребенка 
от различных микробных и вирусных инфекций и аллергических реакций. Грудное молоко содержит относительно большое количество витамина А, группы В, а также витамины К, Е, Д и С. Кроме того, в состав женского молока входит липаза, облегчающая переваривание жиров, и многие другие полезные пищевые компоненты, отсутствующие в коровьем молоке и детских смесях домашнего и промышленного приготовления.Таким образом, грудное молоко представляет собой поистине незаменимый продукт, предназначенный самой природой для вскармливания детей первого года жизни. Оно имеет значительные преимущества перед искусственными смесями для ребенка, матери, семьи и общества в целом. Несмотря на развитие науки и индустрии детского питания, альтернативы грудному вскармливанию нет. Оно превосходит все заменители, в том числе и детские адаптированные молочные смеси промышленного производства.

\section{2. Условия грудного вскармливания ребенка}

Рациональное вскармливание является одним из важнейших условий, обеспечивающих гармоничное развитие ребенка: нормальное созревание различных органов и тканей, оптимальные параметры физического, психомоторного, интеллектуального развития, устойчивость младенца к действию инфекций и других неблагоприятных внешних факторов. Для успешного грудного вскармливания очень важно эмоциональное состояние матери. Процесс кормления грудного ребенка требует сосредоточенности, успокоенности. Окружающие, медицинские работники, члены семьи должны помочь избегать стрессовых ситуаций и различных затруднений. Общение матери с ребенком во время кормления грудью закладывает основы взаимопонимания между ними; мать учится наблюдать и понимать ребенка, выявлять его проблемы и потребности.

В первую неделю после рождения число кормлений составляет 8-20 раз в сутки, включая ночные прикладывания к груди. В этот период кормление осуществляется по «требованию». Следует обеспечить круглосуточное совместное пребывание в одной палате матери и ребенка. Необходимо осуществлять телесный контакт матери и ребенка «кожа к коже», он важен для установления тесной эмоциональной связи между ними. Следует следить за тем, чтобы ребенок был правильно приложен к груди. Во время кормления для избежания трещин ребенок должен охватывать ртом не только сосок, но и ареолу. Нельзя давать новорожденному и грудному ребенку никакой другой пищи и питья, кроме грудного молока, за исключением случаев, когда для этого имеются медицинские показания. Не следует давать ребенку, находящемуся на грудном вскармливании, никаких успокаивающих средств и устройств, имитирующих материнскую грудь (соски и др.). Большое значение имеет полное сцеживание молока после кормления. Оно стимулирует 
дальнейшую лактацию и служит профилактикой лактостаза. При организации грудного вскармливания следует учитывать суточную потребность ребенка в молоке, которая зависит от его массы тела, состояния здоровья и возрастных потребностей в основных пищевых ингредиентах и энергии.

\section{3. Питание кормящей матери}

Кормящая мать должна находиться в спокойной обстановке, достаточно отдыхать, выполнять умеренную физическую работу, гулять на свежем воздухе и спать не менее 8-9 ч в сутки. Совершенно недопустимы курение и употребление спиртных напитков. Кормящая мать по возможности не должна принимать лекарства, так как некоторые из них могут передаваться с молоком и неблагоприятно воздействовать на организм ребенка [4]. Правильное питание и соблюдение кормящей женщиной режима во многом предупреждают гипогалактию. Однако она нередко развивается и у женщин, придерживающихся режима и рационального питания. Кормящая мать обязательно должна получать полноценное сбалансированное питание, так как на образование молока женщина расходует дополнительную энергию, и питательные вещества, а, следовательно, необходимо восполнять эти затраты. Калорийность рациона матери в период лактации должна быть увеличена в среднем на $30-40 \%$ и составлять 2500-3000 ккал/сутки. Количество белка должно составлять около 100 г. (60-70\% животного происхождения), жиров - 85-90 г. (15-20 г. - растительный жир), углеводов - 300-400 г. Этому количеству пищевых веществ соответствует разработанный институтом питания РАМН примерный суточный набор продуктов в составе которого: 200 г. мяса или птицы, 70 г. рыбы, до 600 мл. молока в любом виде (желательно употребление кисломолочных продуктов, 50 г. творога, 20 г. сыра, 400 г. различных овощей, 200 г. картофеля и 200-300 г. фруктов и ягод. Овощи лучше употреблять в натуральном виде или в виде салатов и винегретов. Из круп целесообразнее всего использовать овсянковую и гречневую. Рекомендуется хлеб грубого помола с добавлением отрубей. Следует избегать острых приправ, избытка пряностей, большого количества лука и чеснока, придающих молоку специфический вкус и запах. В период кормления грудью необходимо ограничить употребление продуктов с повышенными аллергенными свойствами: шоколад, какао, натуральное кофе, цитрусовые, мед, орехи. Кормящей матери категорически запрещаются алкогольные напитки, в том числе и пиво. Женщине рекомендуется принимать пищу 5 раз в день за 30-40 мин. Перед кормлением грудью. Количество жидкости (включая супы, овощи и т.д.) должно составлять в среднем 2 л. Матери во время кормления грудью 
следует принимать какой-либо поливитаминный препарат, содержащий витамин D (например, Гендевит - 2 драже в день).

\section{4. Преимущества грудного вскармливания для здоровья ребенка[2]}

Грудное вскармливание обеспечивает гармоничное развитие ребенка: улучшаются показатели его физического, психического и умственного развития; снижается риск развития синдрома внезапной смерти. В первые 3 года жизни (особенно в первый год) ребенок крайне нуждается в прямом контакте с матерью: ласках, прикосновении, поглаживании, укачивании, ношении на руках, речевом и зрительном контакте. Исследования показали, что кормление материнским молоком способствует эмоциональному и психическому здоровью ребенка, улучшает его память и интеллект, снимает стресс. Кроме того, дети, находящиеся на грудном вскармливании, имеют более высокие показатели по части остроты зрения и психомоторного развития, что связано с наличием в молоке ненасыщенных жирных кислот. У них уменьшаются аномалии прикуса благодаря улучшению формы и развитию челюстей. Получающий грудное молоко ребенок меньше подвержен инфекционным заболеваниям желудочно-кишечного тракта и мочевыводящих путей, респираторным инфекциям, менингитам, отитам и пневмониям, развитию пищевой аллергии. Характер вскармливания на первом году жизни в значительной степени определяет состояние здоровья ребенка не только в раннем возрасте, но и в последующие периоды его жизни. Обменные нарушения, возникающие при нерациональном вскармливании младенцев, являются фактором риска развития в будущем ожирения, заболеваний сердечно-сосудистой системы, в частности гипертонической болезни, сахарного диабета, бронхиальной астмы, онкологических и других заболеваний.

\section{5. Преимущества грудного вскармливания для здоровья матери}

Раннее начало грудного вскармливания сразу после рождения ребенка способствует более быстрому восстановлению сил матери после родов, ускоряет сокращение матки за счет выделения окситоцина и уменьшает риск развития послеродовых кровотечений. Исключительно грудное вскармливание в первые 6 месяцев является надежным способом защиты от беременности в результате секреции пролактина и его тормозящего действия на овуляцию в послеродовой период. У кормящих матерей, как правило, быстрее снижается масса тела, возвращаясь к показателям, которые были до беременности. В будущем у них уменьшается риск развития рака молочной железы и яичников. Кроме того, у женщин, кормивших грудью, улучшается минерализация костей и 
снижается степень выраженности остеопороза в пожилом возрасте. Грудное вскармливание и связанные с ним забота и уход за младенцем способствуют улучшению психоэмоционального состояния матери, формированию привязанности между матерью и ребенком, установлению гармоничных отношений в семье. Кроме того, многие исследователи отмечают, что грудное вскармливание способствует установлению прочной духовной связи между матерью и ребенком, остающейся на всю жизнь. В дальнейшем маме, научившейся с первых месяцев хорошо понимать своего малыша, легче не потерять с ним контакт и в периоды возрастных кризисов, и когда ее ребенок станет подростком. Выросший ребенок по-прежнему ощущает, что он любим, и это придает ему уверенности в жизни. А мама, выкормившая одного или нескольких малышей, чувствует себя состоявшейся: чего бы ни достигла она в жизни, самую главную свою задачу она выполнила.

\section{6. Техника прикладывания ребенка к груди[2]}

- Необходимо сесть удобно.

- Взять ребенка на руки, повернуть к себе и прижать к своему телу.

- Новорожденного ребенка следует придерживать снизу за все тельце, а не только за плечи и головку.

- Голова и тельце малыша находятся на одной прямой линии.

- Лицо малыша обращено к маме, а носик - напротив соска.

- Грудь поддерживать снизу указательным пальцем. Большой палец сверху груди, но не близко от соска.

- Помочь малышу - коснуться соском его губ.

- Подождать пока ребенок широко откроет ротик.

- Быстро придвинуть малыша к груди, направить его нижнюю губу чуть ниже соска, а сосок в рот.

- Сосок находится глубоко во рту малыша, его кончик - в самой глубине рта ребенка.

- Нижняя губка ребенка должна находиться чуть дальше от основания соска, чем верхняя.

- Язык ниже ареолы. Он закрывает нижнюю десну и губу.

- Ребенок должен захватить не только сосок, но и ареолу.

- Кормление грудью должно доставлять удовольствие обоим - и матери, и ребенку.

В среднем за сутки следует проводить 8-12 кормлений. При правильном кормлении ребенок сосет медленно, ритмично, глубоко, нет втягивания воздуха (со звуком) и раздувания щек. Большое значение имеет полное сцеживание молока после кормления. Оно стимулирует дальнейшую лактацию и служит профилактикой лактостаза. 


\section{Заключение}

Грудное вскармливание - это бесценный родник здоровья, как для малыша, так и для мамы, оно защищает обоих от многих заболеваний, как в период кормления, так и всю последующую жизнь. Его значимость лишь усиливается на фоне экологических проблем.

Разработанные рекомендации могут быть использованы не только врачами, но также применяться в качестве пособия для обучения правильным методам кормления грудью будующих матерей в школах и университетах.

\section{Список литературы}

1. Голубев В.В. Основы педиатрии и гигиены детей дошкольного возраста : учебное пособие для студентов дошкольных факультетов высших педагогических учебных заведений / В.В. Голубев. - Москва : Академия, 2003. -416 с. - (Высшее профессиональное образование. Педагогика) . - ISBN 5-7695-1386-1.

2. Абольян Л.В., Зубкова Н.З. Современные подходы к грудному вскармливанию ребенка. ММА им. И. М. Сеченова, НИИ общественного здоровья и управления здравоохранением, МОЦМП, Москва. [Электронный ресурс]. URL : http://lib.komarovskiy.net/sovremennye-podxody-k-grudnomuvskarmlivaniyu-rebenka-abolyan-lv-zubkova-nz.html (дата обращения: 25.07.2013).

3. Журнал "Счастье материнства", №3, 2008

4. Грудное вскармливание новорожденных детей и прикорм.

методические рекомендации НИИ питания РАМН "СОВРЕМЕННЫЕ ПРИНЦИПЫ И МЕТОДЫ ВСКАРМЛИВАНИЯ ДЕТЕЙ ПЕРВОГО ГОДА ЖИЗНИ", [ЭЛектронный ресурс]. URL : http://www.papaimama.ru/arts.php?art=est_pit (дата обращения: 25.07.2013). 